\title{
"The Only Hope We Had": United Packinghouse Workers Local 46 and the Struggle for Racial Equality in Waterloo, Iowa, 1948-1960
}

\author{
BRUCE FEHN
}

IN THE LATE 1940s the United Packinghouse Workers of America (UPWA) adopted a logo that represented not only workers' solidarity but racial solidarity as well (see cover). Anna Mae Weems, a member of UPWA Local 46 at Rath Packing Company in Waterloo, Iowa, expressed what that logo meant to African-American meatpacking workers. "The only hope we had of getting our rights," she said, "was when we saw that black hand with the white hand; that gave us the hope." ${ }^{11}$

During the mid-1950s Weems joined with other African Americans in Local 46 to convert into action the "hope" that the UPWA's logo represented. Already active in Waterloo's civil rights movement, Weems responded enthusiastically when Local 46 members asked her to help undermine Rath Packing Company's longstanding discriminatory practices with regard

I heartily thank Merle Davis, John Schacht, Wilson Warren, Marvin Bergman, Herbert Jones, Paul Young, Gerry Roe, and two anonymous readers for the Annals of Iowa for valuable comments and criticism. I also thank Mark Smith, secretary-treasurer of the Iowa Federation of Labor, AFL-CIO, for allowing me access to and permission to cite interviews in the Iowa Labor History Oral Project (ILHOP) held by the State Historical Society of Iowa, Iowa City, Iowa.

1. Anna Mae Weems, interview, Waterloo, 9 May 1986, United Packinghouse Workers of America Oral History Project (UPWAOHP), State Historical Society of Wisconsin, Madison, Wisconsin.

THE ANNALS OF IOWA 54 (Summer 1995). CThe State Historical Society of Iowa, 1995. 
to the hiring and placement of African-American women. In 1954 she was among the first black women to enter Rath's allwhite sliced bacon department, where she persevered in spite of a hostile reception from white women who worked there. Not only did Weems persevere, she earned the respect of white workers who eventually elected her a union steward. Weems also joined Local 46's Anti-Discrimination Committee, which she helped forge into a bastion for antidiscrimination efforts in the Rath plant and in the Waterloo community. ${ }^{2}$

Weems was among the roughly thirty thousand African Americans, in a union of just under 120,000 members, who helped forge an antidiscrimination program that was exceptionally progressive, aggressive, and successful. During the early 1940s, the UPWA's antidiscrimination program went straight to what historian Marshall Stevenson Jr. calls "the essence of racial egalitarianism." Aspects of the program included installation and implementation of nondiscrimination clauses in union-management contracts, rigorous enforcement of color-blind seniority systems, "upgrading of blacks to more skilled occupations, and election of blacks to union offices and policy-making positions." In the postwar decade, the UPWA carried antidiscrimination activities further. In response to pressure from its rank and file, UPWA officials instructed local unions throughout the nation to expose and defeat discrimination whether in the workplace or in the local community. ${ }^{3}$

From the earliest days of union organizing in the late 1930s and early 1940s, members of UPWA Local 46 cultivated the concept of an interracial union organization that formed the bedrock of UPWA's antidiscrimination successes. Interracial unionism prepared Local 46 members to take advantage of the international

2. Anna Mae Weems interview; Jimmie Porter, interview, Waterloo, 8 May 1986, UPWAOHP; Eugene Weems, interview, Waterloo, 7 July 1981, Iowa Labor History Oral Project (ILHOP), State Historical Society of Iowa, Iowa City, Iowa.

3. Marshall Stevenson Jr., "Beyond Theoretical Models: The Limited Possibilities of Racial Egalitarianism," International Labor and Working-Class History 44 (1993), 46; John Hope II, "Preliminary Report, [UPWA] Self-Survey, Study No. 1, Local Unions in the United States: 1949," May 1950, p. 42, in folder 6, box 344, UPWA Records, State Historical Society of Wisconsin, Madison, Wisconsin. 
leadership's decision, in the late 1940s, to move ahead with an aggressive antidiscrimination program. In doing so, Local 46 made impressive gains during the 1950s in breaking down Rath Packing Company's discriminatory practices, which had severely restricted African Americans' opportunities for employment and advancement. The union's antidiscrimination activities also spilled over into the community. In the face of Waterloo's history of segregation and discrimination, the union established ties with other community organizations that propelled many Local 46 members into Waterloo's emerging civil rights movement. Technological and economic changes transformed the meatpacking industry in the 1950 s, affecting disproportionately the jobs of UPWA's minority members and threatening to undermine the union's antidiscrimination accomplishments. Yet Local 46 's success in creating spaces for interracial contact and antidiscrimination initiatives had made union participation a transforming experience, especially for African Americans. For them, Local 46 represented a place of profound possibility-a place where they could realize dreams for social justice in the workplace and community.

THE HISTORY of the UPWA's racial policies and practices contrasts sharply with that of other unions affiliated with the Congress of Industrial Organizations (CIO). Whereas earlier scholars regarded $\mathrm{CIO}$ unions as arenas of hope and progress for black workers, recent scholarship has indicted them for failure to realize their potential as vehicles for racial equality. ${ }^{4}$

4. The CIO unions' harshest critics include Herbert Hill, "Black Workers, Organized Labor, and Title VII of the 1964 Civil Rights Act: Legislative History and Litigation Record," in Race in America: The Struggle for Equality, ed. Herbert Hill and James E. Jones Jr. (Madison, WI, 1993), 263-341; idem, Black Labor and the American Legal System: Race, Work, and the Law (Washington, DC, 1977), 260-73; and Robert J. Norrell, "Caste in Steel: Jim Crow Careers in Birmingham, Alabama," Journal of American History 73 (1986), 669-94. While not entirely uncritical of the CIO, earlier studies by Horace R. Cayton and George S. Mitchell, Black Workers and the New Unions (Westport, CT, 1939), and Herbert Northrup, Organized Labor and the Negro (New York, 1944), offered generally positive evaluations of $\mathrm{CIO}$ unions. A number of recent studies carefully examine how and why $\mathrm{CIO}$ unions faltered in their antidiscrimination and civil rights commitments. These include Michael Honey, Southern Labor and 
Even those who have been most critical of the CIO unions' abandonment of antidiscrimination activities after World War II, however, have cited the United Packinghouse Workers of America as a shining exception. Herbert Hill, for example, sees the UPWA as having been fundamentally different from most American labor unions, "which either actively discriminated against blacks or, at best, regarded their nonwhite membership as a problem to be contained or controlled." The UPWA, in contrast, "promoted the interests of black workers at the workplace and in society as a whole. The uniqueness of this union was that it perceived itself not merely as a collective bargaining agent that provided certain services to its members in return for dues but rather as a labor organization involved in social change."

To explain the UPWA's distinctiveness as an agent of social change, Hill and other historians highlight the UPWA's development as an interracial organization during the formative 1930s and 1940s. Leaders of the UPWA's predecessor organization, the Packinghouse Workers Organizing Committee (PWOC), ${ }^{6}$ knew full well that repeatedly since before the turn of the

Black Civil Rights: Organizing Memphis Workers, 1929-1955 (Urbana, IL, 1993); Robert Korstad and Nelson Lichtenstein, "Opportunities Found and Lost: Labor, Radicals, and the Early Civil Rights Movement," Journal of American History 75 (1988), 786-811; Alan Draper, Conflict of Interests: Organized Labor and the Civil Rights Movement in the South, 1954-1968 (Ithaca, NY, 1994); and Kevin Boyle, "'There Are No Union Sorrows that the Union Can't Heal': The Struggle for Racial Equality in the United Automobile Workers, 1940-1960," Labor History 36 (1995), 5-23. See also note 63 below.

5. Hill, Black Labor and the American Legal System, 273. Historians who share Hill's assessment of the UPWA as an agent of positive social change include Philip S. Foner, Organized Labor and the Black Worker, 1619-1981 (New York, 1981), 290-91; Eric Brian Halpern, "'Black and White Unite and Fight': Race and Labor in Meat Packing, 1904-1948" (Ph.D. diss., University of Pennsylvania, 1989); and Roger Horowitz, Organizing the Makers of Meat: Shop Floor Bargaining and Industrial Unionism in Meatpacking (Urbana, IL, forthcoming). Wilson J. Warren, "The Limits of New Deal Democracy: Working-Class Structural Pluralism in Midwestern Meatpacking" (Ph.D. diss., University of Pittsburgh, 1992), part 3, argues, however, that the UPWA's race relations programs foundered in some midwestern locales.

6. The PWOC began organizing in Chicago in October 1937. It dissolved in 1943 into the United Packinghouse Workers of America. See David Brody, The Butcher Workmen: A Study of Unionization (Cambridge, MA, 1964), 225. 
twentieth century union solidarity in meatpacking had been dashed on the rocks of racial antagonism. Veteran trade unionists remembered that companies hired African Americans to break strikes, which aggravated racial animosity and distrust among white and black workers. They understood that past failures of the Amalgamated Meatcutters and Butcher Workmen to unionize packinghouses stemmed from policies of racial exclusion, which forced African Americans to serve as strikebreakers. And they drew the obvious conclusion-one articulated by Don Harris, a key figure for three decades in Iowa's labor movement - that it was impossible to organize packinghouse workers "unless we was able to break down the hostility between blacks and whites." ${ }^{7}$

The impetus for the UPWA's interracial unionism emanated from Chicago, which, since 1875 , had been the heart of the meatpacking industry. During the Packinghouse Workers' organizing drive of the 1930s, Chicago's union pioneers aggressively recruited African Americans. Many black activists in Chicago's influential local unions subsequently attained prominent leadership positions in Chicago's District 1, which they forged into a powerful center of the UPWA's antidiscrimination activity. Significantly, District 1 leaders encouraged UPWA president Ralph Helstein's predilection to make antidiscrimination and interracial unionism bulwarks of the union's organizational structure. Consequently, in the post-World War II decade, the UPWA's program of antidiscrimination and civil rights influenced union members far beyond Chicago. It affected politics and policy making, to a greater or lesser extent, in each of the

7. Don Harris, interview, 20 August 1982. On the significance of the UPWA's interracial organizing activities, see Halpern, "'Black and White Unite,'" chaps. 3 and 4; Roger Horowitz, "The Path Not Taken: A Social History of Industrial Unionism in Meatpacking, 1930-1960" (Ph.D. diss., University of Wisconsin-Madison, 1990), chaps. 3-5; Paul L. Street, "Working in the Yards: A History of Class Relations in Chicago's Meatpacking Industry, 1886-1960" (Ph.D. diss., SUNY at Binghamton, 1993), chaps. 9 and 10; and Brody, Butcher Workmen, 176-77, 194. On hiring African Americans to break strikes in meatpacking, see William M. Tuttle Jr., Race Riot: Chicago in the Red Summer of 1919 (New York, 1980), 108-156; and James R. Barrett, Work and Community in the Jungle: Chicago's Packinghouse Workers, 1894-1922 (Urbana, IL, 1987), 172-74, 258-59. 
UPWA's nine districts and hundreds of local unions throughout the United States and Canada. ${ }^{8}$

From their headquarters in Des Moines, union leaders in District 3, which included Iowa, Nebraska, and Colorado, worked hard in the 1950s to promote and implement the UPWA's vigorous antidiscrimination program. District 3 director Russell Bull was well known for his commitment to the UPWA's antidiscrimination program, and he promoted it throughout the state. Some UPWA-organized plants in Iowa, such as the Estherville Packing Company in Estherville, John Morrell and Company in Ottumwa, and Tobin Packing Company in Fort Dodge, employed few, if any, African Americans. Consequently, union leaders in those locales were not inclined to develop antidiscrimination initiatives. However, even in "whitest Iowa," to quote a phrase of one of the UPWA's founders, Leslie F. Orear, the UPWA's agitation for antidiscrimination appears to have had an impact. UPWA President Ralph Helstein recalled,

In Estherville, Iowa, there was a guy by the name of Barney Hassel. Barney was five feet two in all directions. I'll never forget his getting up on the floor of this convention. He was very close to tears. He says, "Ralph, what are we supposed to do?" I said, "What do you mean, what are you supposed to do?" And he said, "Well, we got no Negroes living in Estherville, and we can't find any. You know, we drove fifty miles away one night looking for somebody, to see if we could get them to come to work in the plant, and all we could find was a Mexican, and so we brought him. How are we going to have a civil rights program?" I said, "Well, Barney, you got the right intent. Just keep working at it. It'll take care of itself over a period of time. Do what you're doing." Really, the thing had become that much of a part of institutional setup and structure. ${ }^{9}$

8. For details on interracial organizing in Chicago during the 1930s, see Halpern, "'Black and White Unite,'" chaps. 5 and 6; and Street, "Working in the Yards," chap. 10. On the influence of District 1 beyond Chicago, see Rick Halpern, "Interracial Unionism in the Southwest: Fort Worth's Packinghouse Workers," in Robert H. Zieger, ed., Organized Labor in the Twentieth Century (Knoxville, TN, 1991), 171.

9. Ralph Helstein, interview, Chicago, 12 May 1983, ILHOP, also quoted in Shelton Stromquist, Solidarity and Survival: An Oral History of Iowa Labor in the Twentieth Century (Iowa City, 1993), 258. For Leslie Orear's interview on 
Other than Estherville, Ottumwa, and a few other towns, every UPWA local union in Iowa had to respond, in one way or another, to the official requirement that local unions initiate antidiscrimination activities. Some local unions in Iowa, such as Cudahy Local 70 and Swift Local 71 in Sioux City and Jacob E. Decker (an Armour subsidiary) Local 38 in Mason City, had to be prodded to action by international and district leadership. In contrast, Local 46 leaders in Waterloo fully embraced international and district leaders' directives to build an interracial union that would implement a vigorous antidiscrimination program in the plant and struggle for civil rights in the community. ${ }^{10}$

FROM THE OUTSET of the union movement at Rath Packing Company in the late 1930s and early 1940s, Local 46 union pioneers developed organizational strategies that emphasized the importance of interracial unionism. Those tactics, in turn, laid the foundation for the antidiscrimination activities that came later. In those early years, African Americans such as Russell Lasley, Percy Burt, and Robert Burt had joined white activists such as Ray Edsill, Velma Otterman Schrader, and Punchy "CIO" Ackerson to undermine racial hostility in the plant and to organize a union and a work force on an interracial basis. This integrated group of union stalwarts represented in words and deeds the union requirement that white and black workers must bind together in a solid, interracial union that could withstand the packing industry's historical tendency to use race to divide and undermine effective union organization. Both white and black organizers risked discharge as they secretly recruited workers during lunch breaks and din-

UPWA's interracial organizing efforts in Iowa, see his interview with Bruce Fehn, Chicago, 6 June 1990, State Historical Society of Wisconsin, Madison. On Russell Bull's promotion of District 3's civil rights and antidiscrimination program, hear the interview with Tony Fetter (of Cedar Rapids Local 3), Walford, Iowa, 5 May 1986, UPWAOHP.

10. African-Americans in Cedar Rapids Local 3 also successfully relied on international union and District 3 support to break down employment discrimination at the Wilson Packing Company. Hear the UPWAOHP interviews with Local 3 veterans Earl Carr, Cedar Rapids, 18 April 1986; Magnolia Fields, Cedar Rapids, 19 April 1986; and Tony Fetter. 
ner hours, in company locker rooms, and in the plant's cafeteria. After work they went to workers' homes in the effort to sign them up. By 1942, union activists at Rath had garnered enough support to petition for and ultimately win a National Labor Relations Board election. ${ }^{11}$

To bind African-American and other workers at Rath and at other packinghouses with large black work forces into a unified interracial organization, union activists organized the shop floors of packinghouses on a department-by-department basis. From a base of support in one or more departments, organizers identified leaders in other departments, whom they also sought to bring into the union fold. Eventually, organizers would tie the whole system together with a body of powerful stewards who held firm control over workers in their departments. In this organizational process, union organizers were particularly concerned with gaining allegiance from workers on the kill floor, who were in a key position because work stoppages in the kill would stop the flow of meat to the rest of the plant. Often, union members on the kill floor stopped production in order to support workers' grievances in another department in the plant. The prospect of animal carcasses rotting on the disassembly line was a potentially powerful incentive to force company officials to accede to workers' demands. Ironically, this situation empowered African-American workers, because historically management at Rath and other packinghouses tended to assign most African-American men to what it perceived as the most distasteful jobs, including those on the kill floor. Thus, from their positions in Rath's hog kill, where they slaughtered and gutted the animals and sent them on for further processing, Robert Burt, Russell Lasley, and other African-American men were able to wield a great deal of clout. ${ }^{12}$

11. Vernon Dietz, interview, Waterloo, 6 May 1986; Robert Burt, interview, Waterloo, 7 May 1986; Viola Jones, interview, Waterloo, 6 May 1986; Lucille Bremer, interview, Waterloo, 6 May 1986, UPWAOHP; Percy Burt, interview, Waterloo, 31 March 1978, ILHOP.

12. Robert Burt and Lucille Bremer, UPWAOHP interviews; Horowitz, "The Path Not Taken," chaps. 3-6; and Paul Street, "Breaking Up Old Hatreds and Breaking through the Fear: The Rise of the Packinghouse Workers Organizing Committee in Chicago, 1933-1940," Studies in History and Politics 5 (1986), 69-71. 


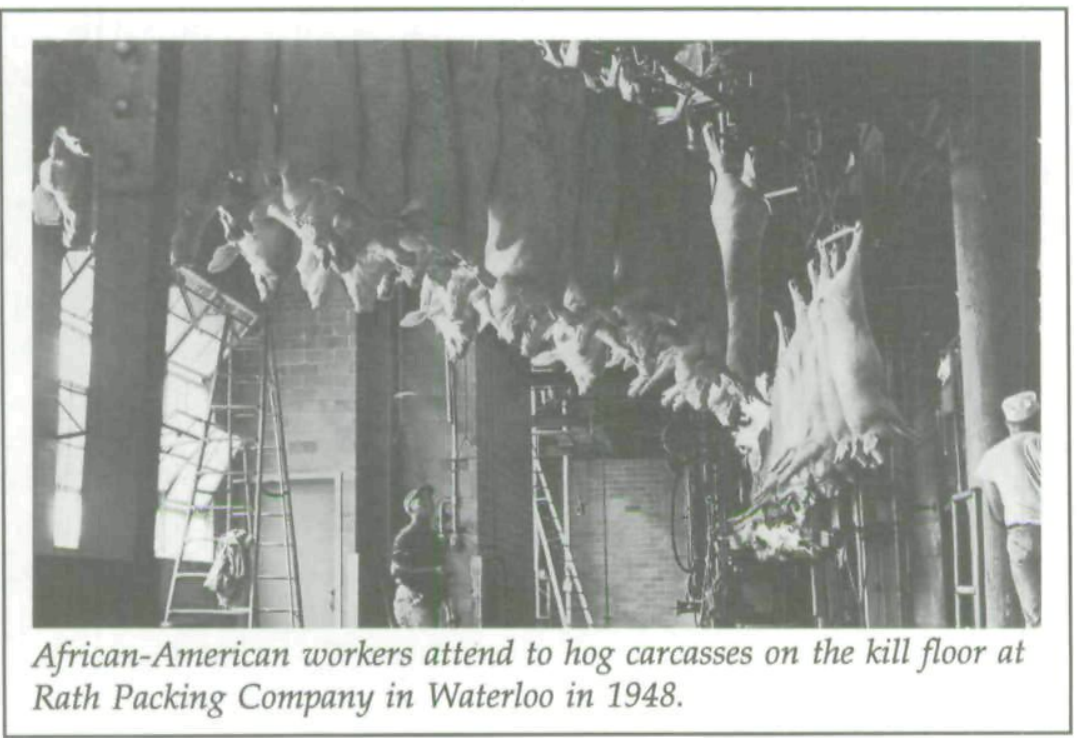

During World War II, Local 46 activists consolidated considerable shop-floor power. Rath was earning tremendous profits from wartime government contracts. Foremen became less aggressive because the company did not want production halted under any circumstances. Union activists took advantage of Rath's determination to keep production going. When Rath added a second shift and hired more workers, the union successfully recruited them. As the union gained strength, Local 46 member Viola Jones recalled that management "didn't have much to say." In support of soldiers fighting overseas, union members honored a wartime no-strike pledge. At the same time, however, Local 46 institutionalized a powerful shop-floor organization and socialized new union members into how the steward system could be used to challenge management authority. Many of the new union members were African-American men, who were impressed with the union's power to represent workers' interests. In the postwar decade, some of these new members would channel the union's shop-floor power in the service of an aggressive antidiscrimination program. ${ }^{13}$

13. Viola Jones, interview; Robert Burt, interview; and Charles Pearson, interview, Peoria, IL, 17 July 1986, UPWAOHP. 
AFTER 1945 and well into the 1950s, the UPWA's international leadership built on the tradition of local, shop-floor, interracial militancy in Chicago, Waterloo, and elsewhere to develop a sustained, hard-hitting campaign against racial discrimination in the meatpacking industry. Union president Ralph Helstein was a key figure in this development. Elected international president in 1946, he was convinced first that the UPWA's continued strength required efforts to gain and hold the allegiance and solidarity of an increasingly diverse work force. A second conviction, closely allied with the first, was that unions must be more than collective bargaining agents; they also had to be agents of social change. Social change, for Helstein, included defeat of discrimination in employment and promotion of civil rights. He sought to create "unity in diversity." To do so, he committed the UPWA to a program of fighting racial discrimination in UPWA-organized plants and to the struggle for civil rights in the communities in which those plants were located. ${ }^{14}$

In that endeavor, Helstein was both prodded and supported by influential African-American leaders inside the unionespecially those in Chicago's Swift, Armour, and Wilson locals, which had large black memberships. African-American leaders in those unions had built their local union programs, to a significant extent, around antidiscrimination. Many of those black leaders attained prominence in District 1, the most powerful of the UPWA's nine district units. They also earned leadership positions in the international union, headquartered in Chicago. From those positions, they agitated for the union's increased commitment to antidiscrimination and civil rights. Subsequently, as historian Rick Halpern observes, union districts and locals outside Chicago felt the "weight of the international union" as it moved rapidly forward on its antidiscrimination programs. ${ }^{15}$

The UPWA's antidiscrimination program gained momentum in the wake of the union's defeat in the nationwide 1948 strike.

14. Hill, Black Labor, 270-71; Ralph Helstein, presidential opening address to the Fourth Constitutional Convention of the United Packinghouse Workers of America-CIO," p. 7, copy in the author's possession courtesy of Rachel Helstein. See also Merle Davis's excellent ILHOP interview with Helstein, relevant passages of which appear in Stromquist, Solidarity and Survival, 255-59.

15. Halpern, "Interracial Unionism in the Southwest," 170-72. 
On March 16 of that year, as many as one hundred thousand UPWA packinghouse workers forced 140 plants in 20 states to shut down after the union and packers failed to reach an agreement over union demands for a wage hike. In Waterloo, 4,600 union workers struck the Rath plant; only 25 to 30 chose to cross the picket line. One month after the walkout began, the relatively peaceful strike entered a confrontational and violent phase when Rath announced on April 17 that it would reopen the plant to anyone who wanted to work. Weary strikers, who had felt the pinch of weeks without a paycheck, became infuriated as police escorted strikebreakers into the plant. In that atmosphere, the number of increasingly nasty confrontations between strikers and replacement workers mounted rapidly. ${ }^{16}$

In the strike's most tragic episode, angry pickets halted African-American Fred Lee Roberts's car as he tried to drive through a crowd of pickets and enter Rath to work for the company. As strikers began to rock his car from side to side, Roberts waved a .45 caliber pistol and shot white union founder Chuck Farrell through the head, killing him instantly. "If there was [going to be] a racial break," recalled Local 46 union founder and divisional steward Charles Pearson, "it would have been at that time-a black man killing a white man." But black and white union members in Waterloo did not break over this potentially divisive tragedy. Rather, Local 46 members vented outrage and frustration against the common foes - Rath Packing Company and strikebreakers. Immediately after the shooting, union members broke down company gates. Scores of blacks and whites, women and men, swarmed the parking lot, smashed windshields, and overturned cars. Some entered the plant to fight strikebreakers and company personnel. In the riot's aftermath, African Americans and whites together confronted soldiers armed with bayonets after Governor Robert Blue called out the Iowa National Guard to maintain order. Three days later they marched together in Chuck Farrell's funeral procession.

16. "Strike Threatens Tie-up of Meat Supply," article in folder 8, box 449, UPWA Records; Waterloo Daily Courier, 8, 16, 18, 19, 20, 26 April, 19 May 1948; Des Moines Register, 17 April 1948; Viola Jones and Vernon and Everett Dietz, UPWAOHP interviews; Dorothy Baker testimony, folder 7, box 3, Local 46 Papers. 
And both African Americans and whites were among the twentyfive men and women indicted for conspiracy to incite a riot, malicious mischief, or assault. ${ }^{17}$

Ultimately, after sixteen exhausting weeks, the international union called off the strike when union solidarity began to show signs of weakening in key plants, such as in Swift and Company's huge flagship plant in Chicago. A demoralized Local 46 membership had to swallow Rath's original contract offer of a nine-cent wage increase. To make matters worse, the company imposed a system of superseniority, which gave seniority to persons who had worked during the strikes. As this allowed strikebreakers to remain in jobs previously held by those who stayed out on strike, superseniority caused deep resentment. ${ }^{18}$

But the union's defeat did bring forth a propitious moment for the UPWA's African-American membership. In the strike's aftermath, union leaders feared and suspected that the packing companies would again use race to divide workers and open UPWA-organized plants to raids by rival unions - either company unions or the AFL's Amalgamated Meat Cutters and Butcher Workmen. To counter any such developments, President Helstein and other UPWA leaders decided on a plan to energize the union's antidiscrimination program. Spurring them, too, was the desire to have a program beyond the companies' power. As Helstein put it, the UPWA wanted to have a program "outside of an area in which the companies could screw us" - one that would demonstrate positive action and focus the attention of the UPWA's demoralized rank and file. ${ }^{19}$

To help implement the program, Helstein hired John Hope II, a member of Fisk University's Race Relations Department, to

17. Charles Pearson, UPWAOHP interview. See also Fred Lee Roberts testimony, p. 20, and Young [no first name recorded] testimony, p. 10, box 3, Local 46 Papers. The Waterloo Daily Courier provided extensive coverage of the shooting and its aftermath in its issues of 20-23 May 1948. See also Chicago Tribune, 21 May 1948. For additional details on the riot and subsequent trials, see trial testimony in box 3, Local 46 Papers.

18. Halpern, "'Black and White Unite,'" 528-29. On superseniority's effects at Rath, see Richard Price, interview, Waterloo, 9 July 1981, ILHOP.

19. Helstein's words are cited in Halpern, "'Black and White Unite,'" 531-32. Helstein also makes this point in his ILHOP interview. 
conduct a comprehensive survey of race relations in the UPWA. Hope's survey examined the extent to which UPWA locals implemented mainstay issues of industrial unionism. For example, it measured the UPWA's ability to pressure companies to promote minority union members to higher paying jobs and more skilled positions. It evaluated the unions' success in electing minority members to union office and policy-making positions. And it determined whether local unions had challenged the segregated facilities that remained inside some packing plants. Going beyond traditional bedrock concerns of industrial unionism, the survey also investigated whether unions encouraged "mixed participation" in both business and social activities, whether minority union members suffered discrimination in local communities, and whether they received legal justice and "protection by police and against brutality from the police." The survey also reported on community patterns of segregation that denied minority access to public facilities, such as swimming pools, and to private businesses, such as restaurants and taverns. Finally, Hope's research monitored the degree of racism and prejudice among local leadership and rank and file. ${ }^{20}$

When the UPWA began to publicize Hope's survey findings in 1950, it revealed that the union's effort to implement its antidiscrimination principles had yielded mixed results. Hope's survey found that the UPWA intended to hold members to an advanced standard of egalitarian practice, and it disclosed a high level of African-American participation in union affairs. It also showed that African Americans represented a growing minority among union membership, and that local unions had opened jobs in packinghouses that were previously closed to blacks. Furthermore, the survey indicated that African Americans had been integrated into union leadership positions and that there was widespread "mutual respect" among "union members and fellow workers ... notwithstanding some blemishes." On the downside, however, the survey demonstrated that highly skilled jobs often remained closed to black workers and that racial prejudice still lingered in the ranks of union

20. Hope, "Preliminary Report," 40-44 (the quoted phrase is on p. 44); John N. Popham, "Union to Examine Aid to Minorities," New York Times, 17 July 1949. 
members. Finally, the survey results disclosed that union initiatives to confront discrimination in local communities were "dangerously" weak. ${ }^{21}$

THE UPWA used Hope's survey findings to justify expanding its antidiscrimination activities. In 1950 the UPWA established an Anti-Discrimination (A-D) Department and a Convention Committee on Problems of Discrimination. The latter committee crafted far-reaching resolutions demanding that local unions fight in-plant segregation and packers' discriminatory hiring policies. Resolutions adopted at the 1950 convention also required local unions to press for inclusion of antidiscrimination language in collective bargaining agreements. After delegates to the UPWA's 1950 convention passed the resolutions, union leaders assigned to the Anti-Discrimination Department the task of translating words into action. To increase both the status and the visibility of the A-D Department, the UPWA appointed Russell Lasley, an international vice-president and an AfricanAmerican Local 46 veteran, as head of the department. The international's leadership also instructed local unions to create their own antidiscrimination committees, and directed Lasley and his staff to monitor and assist local unions with their antidiscrimination activities. ${ }^{22}$

The UPWA leadership's decision in 1951 to hire Myles Horton as education director also signaled the union's resolve to pursue racial equality. Horton was well known as a founder and director of the Highlander Folk School in Monteagle, Tennessee, which in the 1950s provided residential training for civil

21. Anti-Discrimination Committee, "Summary and Analysis of UPWA Human Relations Survey, Kansas City Area," n.d., p. 3, folder 12, box 344, UPWA Records; John Hope II, "The Self-Survey of the Packinghouse Union: A Technique for Effecting Change," Journal of Social Issues 9 (1953), 29-31; idem, Equality of Opportunity: A Union Approach to Fair Employment (Washington, DC, 1956), 100-108; Foner, Organized Labor and the Black Worker, 291; John N. Popham, "Fisk Unit Directs Union Bias Studies," New York Times, 4 July 1950.

22. Hope, "Self-Survey," 30-32; William Kornhauser, "Labor Unions and Race Relations: A Study of Union Tactics" (M.A. thesis, University of Chicago, 1950), 154-55; Halpern, "'Black and White Unite,'" 532; Foner, Organized Labor and the Black Worker, 291. 
rights activists. Many UPWA members attended the Highlander Folk School's workshops in Tennessee, where they developed union-based strategies to promote civil rights and combat discrimination. Many others participated in local leadership schools. For example, Local 46 members attended an integrated leadership session at Clear Lake, Iowa, where they learned the importance of representing the interests of all workers - white and black. Although Horton remained as UPWA's education director for less than two years, his staff's work left an indelible imprint on the UPWA. "The leadership schools," one scholar observed, "led to the breakup of formerly all-white departments and to an increase in the number of black, Mexican-American, and women stewards. ${ }^{\prime 23}$ Furthermore, the leadership schools spurred local union leaders to confront discrimination in communities as well as in the packinghouses.

Local unions responded with varying degrees of enthusiasm and commitment to the UPWA's antidiscrimination program. ${ }^{24}$ In the South, some locals actually left the UPWA to protest its policies, but in some places the union successfully broke down such symbols of segregation as segregated locker rooms, separate pay lines, and segregated cafeteria sections for white and black workers..$^{25}$ In Iowa, union locals also responded variously to the UPWA's call for antidiscrimination initiatives. In early 1952, Russell Lasley decided to pay a personal visit to local union leaders in Sioux City after they had failed to investigate

23. John M. Glen, Highlander: No Ordinary School, 1932-1962 (Lexington, KY, 1988), 124. See also Aimee Isgrig Horton, The Highlander Folk School: A History of Its Major Programs, 1932-1961 (Brooklyn, NY, 1989), 198, 295n; and Jeff Zacharakis-Jutz, "'Straight to the Heart of the Union': Workers' Education in the United Packinghouse Workers of America, 1951-1953" (Ph.D. diss., Northern Illinois University, 1992).

24. Wilson J. Warren, "The Limits of Unionism in Midwestern Meatpacking Communities: Patterns of Internal Strife, 1945-1955," paper presented at the Scholars Seminar, "Work and Community in Twentieth Century Meatpacking," Center for Recent United States History, Iowa City, Iowa, 15 April 1995.

25. Foner, Organized Labor and the Black Worker, 291; Hill, Black Labor, 272-73, 416n; Hope, "Self-Survey," 28; Halpern, "Interracial Unionism," 175; and Moses Adedeji, "Crossing the Color Line: Three Decades of the United Packinghouse Workers of America's Crusade against Racism in the Trans-Mississippi West, 1936-1968" (Ph.D. diss., North Texas State University, 1978), 70-76. 
alleged incidents of police brutality against African Americans. In the course of his investigation, Lasley discovered that the Sioux City locals had neither dismantled the packers' Jim Crow locker facilities nor challenged the companies' rampant discrimination against African-American women. As a result of ensuing pressure from Lasley and his staff, the Sioux City locals organized a campaign to eliminate segregated locker facilities and take action against the companies' discriminatory hiring and placement practices. ${ }^{26}$

In contrast to the situation Lasley found in Sioux City, he discovered in Waterloo that conditions were ripe, and Local 46 was ready, to challenge discrimination at Rath and in the community. Compared with such other Iowa packing towns as Ottumwa, Fort Dodge, Mason City, and Estherville, the Rath plant had a relatively high percentage of African Americans in its work force. Rath had always been one of the city's largest employers of African Americans; by the mid-1950s, nearly one thousand of Rath's approximately 6,500 employees were African American. Most of Rath's black workers were relatively new, having entered the plant sometime between 1950 and 1955, when black representation in Rath's work force increased from 7 percent to 15 percent. This "demographic explosion" coincided with the largest influx ever of African Americans into Iowa and Waterloo. ${ }^{27}$

In the early 1950s, this mass of new African-American workers joined Local 46 veterans, such as Robert Burt, Percy Burt, and John Pearson, who were eager to take action against inplant discrimination. The veterans preferred negotiation with the company rather than strikes or other forms of direct action to pressure management. African-American Charles Pearson was more of a firebrand. From his position as divisional steward in the hog kill's second shift, he continually promoted more aggressive measures, such as work stoppages or slowdowns, to support antidiscrimination initiatives. Pearson established a

26. Lasley to Russell Bull, "Confidential Report," [1952], pp. 2-3; Vina Simmons to Lasley, 18 February 1952, folder 16, box 348, UPWA Records.

27. Louis Bultena and Harold Reasby, "Negro-White Relations in the Waterloo Metropolitan Area," unpublished paper, Iowa State Teachers College, 1955, p. 9, copy in folder 13, box 347, UPWA Records; Wilson J. Warren, "Limits of New Deal Social Democracy," 608 (appendix B, table III). 
considerable following among a younger generation of African Americans, including Anna Mae Weems and Jimmie Porter. Pearson instructed Weems, Porter, and others to seek out instances of company discrimination and to use the union apparatus to disrupt production if the company was slow to move on grievances involving discriminatory employment practices. ${ }^{28}$

In the development of antidiscrimination initiatives, African Americans had the steadfast support of an ardent group of antiracist whites. Among these white union members, Punchy Ackerson and Lowell Hollenbeck loom large in the recollections of Local 46's African-American members. Ackerson was instrumental in the union's founding and urged African Americans to become active in the union. Hollenbeck organized ad hoc meetings of African-American and white workers, where he encouraged them to use direct action tactics to oppose discrimination. Both Ackerson and Hollenbeck constantly preached about the need for and benefits of an interracial organization. Other white workers actively supported Local 46's antidiscrimination initiatives, and they joined forces with African Americans to overcome resistance from workers who were uncomfortable with the union's development as an instrument for racial equality. ${ }^{29}$

Despite these relatively auspicious circumstances - a large black work force, militant white and African-American leadership, and international mandates to fight for racial equalitythe effort to defeat discrimination at Rath required tenacity. For decades Rath's management had tended to funnel black workers into the most undesirable jobs. At Rath and other packinghouses, this system reinforced white solidarity and race consciousness, and thereby divided the work force along racial lines. ${ }^{30} \mathrm{~A}$ classic example of this was in the sliced bacon department, where management had concentrated white women's labor. Paid on incentive systems, many of these white women earned good wages. Often assembled in small production gangs, they

28. Charles Pearson and Jimmie Porter, UPWAOHP interviews.

29. Robert Burt and Charles Pearson, UPWAOHP interviews. For the viewpoint of a union activist uncomfortable with the union's antidiscrimination activities, hear Goldie Lamb, interview, Waterloo, 10 May 1986, UPWAOHP.

30. Waterloo Daily Courier, 21 April 1948. 
sometimes developed a remarkable degree of group identityan identity that was perhaps strengthened by company efforts to make sliced bacon a "showcase" department. In many packinghouses, managers proudly displayed their sliced bacon departments' relatively clean environs and wholesome look to visitors touring the plants, and they feared that the presence of African-American women would spoil the portrait of pristine conditions inside their packing facility. ${ }^{31}$

Local 46 decided that Rath's traditional policy of discrimination against African-American women would be its first point of attack. In this endeavor, they joined other UPWA locals that decided to assist members with the lowest wages and least power, namely African-American women. In packing plants nationwide, African-American women had for decades suffered the most egregious forms of racial and gender discrimination. Whether at Rath, Armour, Swift, or any other packing operation, African-American women were the last hired and first fired. Further, management tended to assign them to the worst jobs. For example, African-American women were overrepresented in hog casings departments, where they flushed worms and feces from the animal's intestines. ${ }^{32}$

Rath's discrimination against African-American women took a form somewhat different from that found in other companies. Rath's management refused to hire African-American women into any jobs in production departments. Instead, the company confined black women to janitorial service. Ada Tredwell, who

31. Erdman B. Palmore, "The Introduction of Negroes into Four White Industrial Departments" (M.A. thesis, University of Chicago, 1954), 25-33; interview with Vicki Starr in Rank and File: Personal Histories by Working-Class Organizers, ed. Alice and Staughton Lynd (Boston, 1973), 79; Robert Slayton, Back of the Yards: The Making of a Local Democracy (Chicago, 1986), 83; Rowena Moore, interview, Omaha, 5 June 1986; and Ada Burt Tredwell, interview, Waterloo, 29 July 1986, UPWAOHP. On sliced bacon as a segregated "showcase" in a packinghouse, see the ILHOP interview with Ralph Helstein, also in Stromquist, Solidarity and Survival, 258.

32. Alma Herbst, The Negro in the Slaughtering and Meat Packing Industry of Chicago (New York, 1932), 86, 90; Mary Elizabeth Pidgeon, The Employment of Women in Slaughtering and Meat Packing, Women's Bureau Bulletin No. 88 (Washington, DC, 1932), 9, 51, 59, 61; Bruce R. Fehn, "Striking Women: Gender, Race, and Class in the United Packinghouse Workers of America (UPWA), 1938-1968" (Ph.D. diss., University of Wisconsin-Madison, 1991), 153-54. 
in 1941 was one of the first black women Rath hired, enjoyed the wage hike from the five dollars per week she was paid in private domestic service to the $\$ 12.50$ she received at Rath. However, Tredwell regarded the janitorial work as "terrible," as it required that women get down on their hands and knees to scrub and wax floors. Confinement to such drudgery seemed to confirm the odious notion that African-American women were somehow suited to the "domestic labor" to which the great majority were confined and which they heartily disdained. ${ }^{33}$

In a letter to Russell Lasley, Reuselle Louise Sheppard informed him of her difficulties in securing employment at Rath in the early 1950s. She found prospects for a job there very attractive in a city where otherwise "we can only get jobs as maids or cooks - for peanuts - hard, long hours - I know, since I've worked in that field." She reported to Lasley, "I'm leaving no stone unturned in my attempt to secure a job at Rath Packing Co." She understood full well the obstacles faced by African Americans and women. As she explained to Lasley, "I'm a colored woman or by now I would no doubt have a job there." ${ }^{134}$

To combat this pattern of hiring discrimination, Local 46 officials implemented a project first to expose and then to eliminate discrimination against African-American women. They relied on an important precedent established in 1950 at Swift and Company's Chicago plant. In the Swift case, the union sent black and white women to the personnel office to apply for jobs, enabling them to gather convincing evidence that management hired white women but not equally qualified black women for the pork trim department. Lasley's Anti-Discrimination Department used the evidence to file a grievance against the company, charging that Swift's refusal to hire African-American women violated the labor-management agreement, which required Swift to "give fair and reasonable consideration to any applicant or employee regardless of race, sex, color, creed, nationality or membership in the Union." The union sent the evidence of the case to a federal arbitrator, who in 1951 determined that Swift had discriminated against thirteen African-American women job

33. Ada Tredwell, UPWAOHP interview.

34. Sheppard to Lasley, 30 October 1952, folder 1, box 348, UPWA Records. 
applicants. He then ordered the company to hire the women and give them back pay and retroactive seniority. ${ }^{35}$

The UPWA's Anti-Discrimination Department gave the Swift case wide publicity, and other local unions used it as a basis for challenging hiring discrimination. In Waterloo, Local 46's AntiDiscrimination Committee recruited African-American and white women to apply for jobs in the plant, including jobs in the sliced bacon department. Using the procedure learned from Swift Local 28, Local 46's A-D Committee members monitored Rath's hiring practices and documented discrimination against AfricanAmerican women. Confronted with the evidence, Rath officials agreed to allow black women who already worked for the company as janitors to transfer into production jobs. ${ }^{36}$

Union members recognized, of course, that this new policy continued to discriminate against African-American applicants who applied "off the street." To halt that discrimination, union members filed grievances accusing Rath of violating antidiscrimination clauses of its collective bargaining agreement. Local 46's antidiscrimination committee also called a meeting with Rath officials "to demand they hire Negro women directly into production work as the contract provides." Finally, in October 1953, Rath capitulated to union pressure, hired a black woman, and placed her directly into an all-white department. A few months later, the company agreed to hire and place several black women in the all-white sliced bacon department. ${ }^{37}$

Local 46's antidiscrimination struggle did not end, however, with the company's agreement to hire African-American women into previously all-white departments. More was required. In sliced bacon, white women who were intent on maintaining

35. The quote is in Hill, Black Labor, 271. See also Fehn, "Striking Women," 168-69; and "Action Against Jim Crow," n.d., folder 13, box 347, UPWA Records. 36. Russell Lasley to Russell Bull, 27 October 1950, folder 5, box 297, UPWA Records; Report of International Anti-Discrimination Department, n.d., p. 3, folder 15, box 342, UPWA Records.

37. Russell Lasley to Reuselle Louise Sheppard, 4 November 1952, folder 1, box 348, UPWA Records; Haxel Hull, field reports to the UPWA Anti-Discrimination Department, 25 October and 1 November 1953, folder 3, box 347, UPWA Records; Ada Tredwell, Robert Burt, Jimmie Porter, and Lyle Taylor (Waterloo, 7 May 1986), UPWAOHP interviews. 
their race-based privileges walked out of the department as soon as the African-American women entered. In response, Rath prepared to fire the new African-American hirees. Local 46 activists countered with a show of shop-floor power. The hog kill department threatened to quit work and leave the hog carcasses to rot on the chain if the company fired the black women. Under this threat, the company informed the white women that either they would return to work or they would be replaced. ${ }^{38}$

These efforts to desegregate the plant gradually changed the structure of employment opportunity at Rath for Local 46's minority members. In subsequent years, African-American women and men at Rath used the foothold in sliced bacon to desegregate mechanical gangs, frozen foods, canning, dry sausage, wet sausage, the stuffing room, and other departments. ${ }^{39}$ Further, African Americans and their white allies acted on UPWA mandates to seek out and expose instances of discrimination in the community and take action against them.

THE UPWA'S INTERNATIONAL LEADERSHIP understood that racial discrimination in schools, housing, and public accommodations reinforced workplace discrimination. President Helstein eloquently summarized the union's viewpoint.

It is not enough to eliminate discriminatory practices in the plant, but we have to do it also in the community, because you can't work with a man all day long, get along with him, and you go one way and he goes another, and then pick up where you left off the next day. Sooner or later this was going to create schisms, misunderstandings, and problems, so that it was essential to carry on this kind of activity in the communities in which you lived as well as in the plant. I suppose that in an important sense this reflected the age old fight within the American labor movement

38. Ada Tredwell and Robert Burt, UPWAOHP interviews.

39. Hope, "Self-Survey," 35; Ada Tredwell, Anna Mae Weems, and Robert Burt, UPWAOHP interviews. In an important precedent-setting case in early 1953, Local 46 won an arbitrator's award opening jobs in Rath's mechanical gang to African Americans on the basis of seniority and qualifications. See "Arbitration of Grievance, Local 46, UPWA-CIO against Rath Packing Company, Waterloo, Iowa" (1953), cited in Hope, "Self-Survey," 35. 
... between social unionism on the one hand and business unionism on the other. We felt the union was something more than just an economic instrument. If it was going to fulfill its function as an economic instrument, it also had to be a social instrument to bring about change and progress.

The UPWA's executive board agreed that "we cannot protect our own ranks against the evils of discrimination if such evils are prevalent in the communities in which we live. ${ }^{\prime 40}$

As part of the effort to make the UPWA a "social instrument," black and white delegates assembled in alternate years at antidiscrimination conventions. There they analyzed how companies and communities perpetuated discrimination, and they framed resolutions to fight discrimination in the community as well as inside packinghouses. To ensure implementation of those resolutions, which in most cases evolved into convention mandates, Russell Lasley and the Anti-Discrimination Department kept pressure on local unions. With a barrage of directives, the A-D Department instructed local unions to attack employment, housing, and other forms of discrimination, and Lasley and his staff held local unions accountable for creating and implementing antidiscrimination programs in their local communities. "If you hadn't something going on," Local 46 activist Jimmie Porter recalled, "they'd call the roll on your ass. This was mandated, it wasn't something just passed, and your district director was going to account for what you've done. ${ }^{\prime 41}$

A formidable task faced Local 46 members as they acted on union mandates to end racial discrimination and inequality in Waterloo and the surrounding area. Waterloo was a city with long-standing and deep racial divides. African Americans first came to the city in significant numbers between 1910 and 1914 to serve as strikebreakers for the Illinois Central Railroad. These

40. Helstein, ILHOP interview, quoted in Stromquist, Solidarity and Survival, 256; Officers' Report, Executive Board Meeting, 17-19 July 1952, folder 1, box 347, UPWA Records. See also Hope, Equality of Opportunity, 2.

41. Jimmie Porter, UPWAOHP interview. In 1950, Lasley encouraged District 3 and Local 46 leadership to have African Americans "constantly use . . . restaurants, motels, and entertainment spots ... in order to sustain the momentum for integration of public places and facilities in Waterloo." Lasley to Filliman, 22 March 1958, folder 7, box 343, UPWA Records. 
early migrants from Mississippi settled near the Illinois Central shop yards next to the Cedar River on Waterloo's east side. Most suffered from inadequate housing; some actually lived in boxcars for a time. They suffered as well the hostility of many of Waterloo's white residents, who supported Illinois Central workers' demands for higher wages. Waterloo journalists fanned racist sentiments with sweeping generalizations about "vice and criminality" on Waterloo's east side. An "unofficial color line" emerged, keeping African Americans from entering many restaurants and cafes and restricting blacks to particular areas in theaters. ${ }^{42}$

In spite of racism in the North, a slow migration of African Americans from rural Mississippi expanded Waterloo's black community in the 1920 s and ' 30 s. Encouraged by relatives who enjoyed comparative economic prosperity, the new residents joined a community that tended to divide rigidly between white and black on the west and east sides of the Cedar River. During the 1940s, Waterloo's African-American population jumped 73 percent. In the 1950s the population leapt upward again, this time by 87 percent, one of the largest percentage increases in African-American urban residency in the nation. ${ }^{43}$

Although African Americans organized churches, social service agencies, and benevolent societies to help the new residents, the population increase strained community resources. Unable to make inroads into white neighborhoods, new residents who entered Waterloo in the 1940s and '50s crowded into the east side and north end. Little new housing construction took place, and older houses deteriorated rapidly, having been cheaply built for black residents in the 1930s. African Americans who could afford to move were unable to do so because

42. "Hearing Before the Waterloo Commission on Human Rights, Waterloo, Iowa," 7 September 1967, State Historical Society of Iowa, Iowa City, Iowa; Robert Neymeyer, "May Harmony Prevail: The Early History of Black Waterloo," Palimpsest 61 (1980), 85-89. See also Bultena and Reasby, "Negro-White Relations in Waterloo," 3-4; and Glenda Riley, Cities on the Cedar: A Portrait of Cedar Falls, Waterloo, and Black Hawk County (Parkersburg, 1988), 42-43.

43. "Hearing Before the Waterloo Commission on Civil Rights"; Bultena and Reasby, "Negro-White Relations in Waterloo," 2-4. The population statistics are from Riley, Cities on the Cedar, 72. 
of racist covenants in lot abstracts, discrimination by loan agencies, threats against blacks who tried to move into white neighborhoods, and discriminatory behavior on the part of real estate agents. Housing discrimination meant that African Americans could only move to areas adjacent to the black community. "White flight" enlarged the segregated area, but blacks were not able to break out of it. ${ }^{44}$

As Waterloo settled into the segregated patterns characteristic of most northern cities, African Americans endured poor housing and unpaved streets and sidewalks and received inferior police protection and other city services. African-American children attended segregated elementary schools. Patterns of discrimination characteristic of other cities also kept African Americans out of public facilities such as swimming pools and restaurants. Racist behavior and attitudes, of course, accompanied discrimination. For example, the Waterloo Daily Courier, the city's main newspaper, reinforced discriminatory patterns with its designation of the race of persons charged with crimes - if they happened to be African American. According to Russell Lasley, the paper gave the impression that "everything bad happens on the 'North End."' The paper, he claimed, did nothing to "dignify the Negro." Rather, African Americans believed the paper's news coverage accentuated negative aspects of their community experience and failed to report on the positive. ${ }^{45}$

Undaunted by the magnitude of the problems they faced, Local 46 members addressed issues of discrimination in their community. In 1947, two years before the international office launched its formal antidiscrimination campaign, an interracial group of Local 46 members established a Race Relations Committee, which emphasized education and interracial harmony

44. Neymeyer, "May Harmony Prevail"; "Hearing Before the Waterloo Commission on Human Rights," 2 and table on 3; Bultena and Reasby, "NegroWhite Relations in Waterloo," 2-9; "School Desegregation in Waterloo, Iowa: A Staff Report of the United States Commission on Civil Rights," August 1977, p. 1; Robert Burt and Anna Mae Weems, UPWAOHP interviews; Percy Burt, ILHOP interview.

45. "Hearing Before the Waterloo Commission of Civil Rights"; Riley, Cities on the Cedar, 72; Russell Lasley to Vi Norman, 26 August 1932, folder 1, box 348, UPWA Records. 
and urged closer contact among all Waterloo citizens. In 1948, members of the committee participated in weekly radio panel discussions and dramas that depicted "the evils of hatred and prejudice." Through the committee's initiative, discussions of race issues were held in local high schools. The committee also helped to desegregate Waterloo's police department and win the appointment of an African American to the board of directors of the Community Fund. In addition, it spearheaded the formation of the Waterloo Inter-Racial Commission, a coalition of twenty-four local organizations that pressured hotels and restaurants to serve minority patrons and helped to desegregate the YMCA's Men's Club. ${ }^{46}$

The Race Relations Committee's conciliatory approach recorded some successes, but its activities did not make substantial inroads into the employment discrimination African Americans suffered in Waterloo. Moreover, many public establishments continued to refuse service to African Americans. Accordingly, a segment of Local 46's membership decided to move the union's antidiscrimination activities onto a more aggressive and confrontational track. In the early 1950s Charles Pearson, O. C. Smith, and other African Americans worked with white activists Lowell Hollenbeck and Punchy Ackerson to confront owners of local businesses and demand that they end discrimination against African-American patrons. They did so by organizing integrated delegations of union members and local residents who entered taverns, cafes, and restaurants and demanded service. ${ }^{47}$

This group also used the law to back up direct action. In early 1952, for example, the union filed charges against the owner of a tavern who refused to serve blacks. Although the owner was fined for violating Iowa's civil rights law, he persisted in his refusal to serve African Americans, so Local 46 members began to picket his tavern. Ultimately, the owner capitulated and began to serve blacks. Following this incident, the local set up a "caravan" of black and white workers who

46. "Local 46 Yearbook," p. 9, folder 1, box 37, Local 46 Papers; Minutes, Second Annual Constitutional Convention, District No. 3 Council, 13-15 February 1948, pp. 39-40, folder 1, box 12, Local 46 Papers; Waterloo Daily Courier, 18 April 1948.

47. Charles Pearson, UPWAOHP interview. 
moved from one public establishment to another and successfully integrated other taverns and restaurants in Waterloo. ${ }^{48}$

Local 46 members also lobbied city officials to establish municipal regulations that would discourage discrimination. In 1953 union leaders presented to Waterloo's city council a "Resolution on Discriminatory Practices in the City of Waterloo, Iowa." The resolution demanded that the city take action against the "many" businesses that "openly practice discrimination against the minority races" in "flagrant" violation of Iowa law. The local called upon the mayor of Waterloo "to write to each and every motel, hotel, cafe, restaurant, tavern, theater . . . quoting the law with respect to serving members of minority races." The union sent 41 copies of the resolution to other Waterloo civic and labor organizations, asking them to adopt similar resolutions and send them to the mayor. In addition, they sent a news release to the Waterloo Daily Courier and local radio stations, which gave their resolution wide publicity. The union also organized a meeting of all those "who have pledged their support to us on wiping out community discrimination. ${ }^{\prime 49}$

Local 46 members did not merely wait for the city of Waterloo to take action. The union designed and implemented its own procedures to expose discrimination by local businesses. In late 1953, members of the A-D Committee conducted a survey of Waterloo establishments and found that some of them openly admitted that they discriminated against African Americans. After union members discussed their findings with Waterloo's mayor and county attorney, at least one of the restaurants located near the Rath plant apparently decided to reverse its policy, for the establishment served the racially integrated groups of Local 46 members sent to verify its practices. ${ }^{50}$

On at least one occasion, Local 46's fight against communitybased discrimination had an effect beyond Waterloo. On a late

48. John Davidchik, Field Report, District \#3, 16 February 1952, folder 16, box 348, UPWA Records; Jimmie Porter, UPWAOHP interview.

49. Haxel Hull, field reports to the UPWA Anti-Discrimination Committee, 25 October and 1 November 1953, folder 3, box 347, UPWA Records; Bultena and Reasby, "Negro-White Relations in Waterloo," 11-12.

50. Haxel Hull, District 3, field report to UPWA Anti-Discrimination Department, 6 December 1953, folder 3, box 347, UPWA Records. 
June evening in 1952 at Clear Lake, Iowa, UPWA members from Local 46 and Mason City Local 38 were attending one of Myles Horton's leadership training schools. Following a training session, an integrated group of union members tried to enter the Surf Ballroom in Clear Lake to enjoy some entertainment. An employee refused to allow the group to enter, apparently because some members of the group were black. As a result, Isadore "Pat" Patterson, one of the newer generation of Local 46 's African-American activists, filed suit against the Surf Ballroom's manager for violating Iowa's civil liberties law. Although the Ballroom's manager was acquitted on a technicality, the press in Iowa gave the incident wide publicity. An editorial in the Des Moines Register railed against the trial's outcome, accusing the jury of "dodging Iowa's law on equal privileges." Subsequently, the case was among those that union leaders used to inspire their rank and file to agitate for enforcement of antidiscrimination statutes in Iowa and elsewhere. ${ }^{51}$

Such civil rights agitation in the early 1950s inspired new African-American members such as Jimmie Porter. Like so many other African Americans in Waterloo, Porter had migrated north from Mississippi. When he joined the Rath work force in 1954, he found his work in the resin room of Rath's hog kill department arduous, even overwhelming. "I had never worked that hard in my life," Porter recalled, "even in Mississippi." Just as stunning to Porter, however, was the union's impact on the way supervisory personnel conducted relations with workers on the shop floor. To his amazement, the foreman treated him decently, allowing him to take frequent breaks until he adapted physically to the rigors of packinghouse labor. As the union exercised its power on the shop floor, Porter saw that he could "make a difference" and that the union gave him the "opportunity that I never dreamed I would have before" to fight against racial discrimination. Soon, Porter became a stalwart in Local 46 's

51. Des Moines Register, 18 and 19 September 1952. To track the UPWA's efforts to pursue this case, see "HH" [Hazel Hayes] to Russell Lasley [memo], 30 June 1952; Russell Bull to Hazel Hayes, 2 July 1952; Lasley to Art Costello, 29 July 1952; Clive Knowles to Donald Murphy, 18 September 1952; Hy Kornbluh to Lasley, 25 September 1952; and Clive Knowles to Lasley, 19 September 1952, folder 25, box 348, UPWA Records. 
drive to end discrimination at Rath and a leader in the union's antidiscrimination campaigns in the community. ${ }^{52}$

Anna Mae Weems shared Jimmie Porter's dream of changing the economic and social inequities that afflicted Waterloo's African-American citizens. According to Porter, "Weems took over the town and turned it upside down" when she assumed a prominent leadership role in Local 46's antidiscrimination and civil rights activities. As president of the Waterloo branch of the National Association for the Advancement of Colored People (NAACP) throughout most of the 1950s, Weems was already a leader in Waterloo's African-American community when she helped Local 46 undermine Rath's discriminatory job placement policies in 1954. Soon she became an active member of Local 46's Anti-Discrimination Committee and merged its activities with those of Waterloo's NAACP. Under her leadership, the NAACP and UPWA struggled together to open job opportunities for African Americans in local grocery stores and to force the Waterloo Daily Courier to stop publishing the race of AfricanAmerican criminals. She used her clout with both organizations to file charges against Waterloo restaurants that refused to hire blacks. She also mobilized support from the Black Hawk County Labor Council, Local 838 of the United Auto Workers (which represented workers at the John Deere Tractor Works), and other labor bodies in fighting employment discrimination and racism in Waterloo. As chair of Local 46's Human Relations Committee, Weems encouraged union members to be more aggressive in fighting discrimination inside the Rath plant. In 1958, for example, she challenged Rath's refusal to hire African Americans in its front office. Later, she mobilized efforts to open up additional employment opportunities for blacks at John Deere and Waterloo's public utility corporation..$^{53}$

As Porter, Weems, and others challenged economic and social inequality in Waterloo, they also contributed to the burgeoning nationwide civil rights struggle. In 1957, Local 46 joined

52. Jimmie Porter, UPWAOHP interview.

53. Eugene Weems, ILHOP interview; Jimmie Porter and Anna Mae Weems, UPWAOHP interviews; Unemployment, 1958, in the section titled "On the Front Office Front," folder 8, box 387, UPWA Records. 
other UPWA locals to lend financial support to Martin Luther King and the Southern Christian Leadership Conference. ${ }^{54}$ In April 1960 lunch counter sit-ins and demonstrations conducted by integrated groups of Local 46 members at Kresge's and Woolworth's in Waterloo coincided with those of student militants in North Carolina, who also began their "sit-in" campaigns in the spring of that year. ${ }^{55}$

The sit-ins and demonstrations of Local 46 members capped a decade of antidiscrimination and civil rights activity in the Rath plant and the community of Waterloo. Through disciplined use of its powerful shop-floor organization, union members successfully pressured Rath management to quit discrimination and to hire and place African-American women and men in jobs previously closed to them. While breaking down the structure of workplace inequality, Local 46 members also took the fight for racial equality into the community. They converted the union into a bastion of the civil rights struggle in Waterloo, and used the power and organization of union membership to confront segregation in restaurants, bars, and public facilities.

JUST AS LOCAL 46's antidiscrimination program was gaining momentum in the 1950s, however, activists found it increasingly difficult to contend with powerful economic forces that threatened to erode their accomplishments. Aided by the construction of a federal interstate highway system, small, independent meatpacking companies had been establishing operations in rural areas of the Corn Belt and High Plains. These new operators slaughtered livestock near feedlots, boxed the product, and trucked it to market. This was much cheaper than shipping animals by rail, which was the means of supply for "old line" meatpackers such as Armour, Swift, Wilson, and Rath. The new companies, moreover, introduced technologies that increased production and lowered labor costs. They tended to employ

54. "UPWA Fund for Democracy in the South Progress Report," 21 June 1957, folder 2, box 379, UPWA Records.

55. Handwritten minutes and agenda from a meeting of the Local 46 Human Relations Committee, ca. April 1960, Local 46 Papers. See also Lucille Bremer, ILHOP interview; and Jimmie Porter, UPWAOHP interview. 
nonunion workers at wage rates below those negotiated by the UPWA and other unions. ${ }^{56}$

Rath and other old line companies responded to the new competition in ways that threatened the livelihoods of employees. Some packers, such as Armour, closed plants in urban areas and constructed new plants with new equipment in rural areas. Others introduced new production technologies that eliminated jobs. In 1961 the UPWA Research Department reported that, industrywide, 39,100 packinghouse workers had lost their jobs in the previous five years. ${ }^{57}$ Rath kept open its flagship plant in Waterloo; meanwhile, it built new processing and distribution facilities in Iowa, Indiana, Texas, and California. At its Waterloo plant, the company introduced new machinery in order to increase production at reduced cost. ${ }^{58}$

In 1959, members of Local 46's Human Relations Committee were appalled to discover just how dramatically the changes in the 1950s had affected the number and percentage of African Americans employed at Rath. Union statistics revealed that out of a total work force of 6,234 in 1959, only 299 were African American. Just five years earlier, in 1954, nearly one thousand African Americans had worked at Rath, constituting some 15 percent of Rath's total work force of about 6,500. Although their 1959 figures showed that progress had been made in opening skilled positions to African Americans, the union documented a virtual absence of blacks in supervisory and "professional/

56. For discussion of the economic transformation of the meatpacking industry, see Kim Moody, An Injury to All: The Decline of American Unionism (New York, 1988), 179-205; Dorothy Remy and Larry Sawyers, "Economic Discrimination and Stagnation," in My Troubles Gonna Have Trouble with Me: Everyday Trials and Triumphs of Women Workers, ed. Karen B. Sacks and Dorothy Remy (New Brunswick, NJ, 1985), 94-112 (see esp. p. 98 on the implications for minority workers and women). See also Walter A. Fogel, The Negro in the Meat Industry (Philadelphia, 1970). On Rath's adjustments to the new economics of meatpacking, see John Portz, The Politics of Plant Closings (Lawrence, KS, 1990), chap. 4. 57. "Facts and Figures," vol. 14, no. 21, 27 July 1961; ibid., vol. 13, no. 14, 25 April 1960, both in folder 14, box 513, UPWA Records. A U.S. Department of Labor report in 1961, quoted in Remy and Sawyers, "Economic Discrimination and Stagnation," 98, estimated that "at the current production levels, new equipment and new technology have been eliminating 7,000 packing jobs a year."

58. Portz, Politics of Plant Closings, 57-58. 
technical" positions. Most African Americans who had taken advantage of Local 46's successful efforts to open jobs at Rath had entered unskilled positions, so when new economic forces transformed hiring and layoff patterns, the new African-American hirees were among the first to go. ${ }^{59}$

The statistics shook the morale of Local 46's leaders. Some must have agreed with Russell Lasley's assessment that Local 46 apparently had not been vigilant or aggressive enough in its efforts to defeat Rath's predilection to discriminate against black workers. ${ }^{60}$ The deterioration of African-American employment at Rath Packing Company, however, did not derive primarily from a failure of vigilance or militant action against discrimination. Rather, it was the result of the dramatic and fundamental changes that had been taking place in the meatpacking industry since the mid-1950s.

Those developments at Rath and other companies were neither race nor gender neutral. Because Local 46 rigorously enforced its seniority system, new workers were discharged first. Ironically, and tragically, the seniority system, which had been used so successfully to integrate Rath, now resulted in the unemployment of many new, African-American hirees. Further, mechanization, with its attendant loss of jobs, advanced most rapidly in departments where female and African-American workers were concentrated. ${ }^{61}$ By 1957, Rath's new technology had reduced labor needs by 40 to 60 percent in the sliced bacon department. In the sausage department, meanwhile, it had reduced employment from three hundred workers to only twelve, while production levels remained virtually unchanged. ${ }^{62}$ The

59. Handwritten notes and minutes, ca. April 1960, Local 46 Papers.

60. Ibid.

61. Remy and Sawyers, "Economic Discrimination and Stagnation," 98. On the consequences of these developments for female employees in UPWAorganized plants, see Dennis Deslippe, "'We Had an Awful Time with Our Women': Iowa's United Packinghouse Workers of America, 1945-1975," Journal of Women's History 5 (1993), 10-32; and Bruce Fehn, "'Chickens Come Home to Roost': Industrial Organization, Seniority, and Gender Conflict in the United Packinghouse Workers of America, 1955-1966," Labor History 34 (1993), 324-41.

62. "How Mechanization and Plant Closings are Holding Down Packinghouse Employment," 1957, folder 5, box 382, UPWA Records. 
sliced bacon and sausage departments, of course, were the very ones in which African-American women had recently made gains as part of Local 46's antidiscrimination efforts.

IN SPITE OF these unfortunate developments for Rath workers, Local 46's history revealed tremendous possibilities for racial egalitarianism. ${ }^{63}$ Although Local 46 was unable to subdue the race and gender discrimination that accompanied the economic transformation of meatpacking, union members had moved forward for twenty years on a vital program of civil rights and economic opportunity on behalf of minority union members. Local 46's experiences highlighted key factors necessary for the emergence of a dynamic, union-based program of antidiscrimination. These included the union's large black membership, its integrated leadership, African Americans' placement in the union's powerful shop-floor organization, critical support from antiracist whites, participation in the UPWA's leadership schools, and sustained support from the UPWA's international union leadership.

It is not surprising that Charles Pearson, Jimmie Porter, Anna Mae Weems, and other African-American members found inspiration in their union's activities. Local 46 had transformed their dreams for equality into programs that eroded discrimination and promoted civil rights. Anna Mae Weems offered eloquent testimony to that effect. She observed that when the union "started implementing their mandates and putting [AfricanAmerican] people in the packinghouses and demanding that companies do that, that gave us our first real feel and experience in equal opportunity, far superseding the NAACP and the Urban League." ${ }^{\prime 64}$ That quality of hope for the realization of equal opportunity represents an enduring legacy of Waterloo Local 46 and the United Packinghouse Workers of America.

63. For recent controversy over the "possibilities of racial egalitarianism" in the CIO, see Michael Goldfield, "Race and the CIO: The Possibilities of Racial Egalitarianism during the 1930s and 1940s," with responses by Gary Gerstle, Robert Korstad, Marshall Stevenson Jr., and Judith Stein, International Labor and Working Class History 44 (1993), 1-63; and Michael Goldfield, "Race and the CIO: Reply to Critics," ibid. 46 (1994), 142-60.

64. Anna Mae Weems, UPWAOHP interview. 
Copyright of Annals of Iowa is the property of State of Iowa, by \& through the State Historical Society of Iowa and its content may not be copied or emailed to multiple sites or posted to a listserv without the copyright holder's express written permission. However, users may print, download, or email articles for individual use. 